\title{
Patterns of Abundance, Host Use, and Everglades Virus Infection in Culex (Melanoconion) cedecei Mosquitoes, Florida, USA
}

\author{
Isaiah J. Hoyer, Carolina Acevedo, Keenan Wiggins, Barry W. Alto, Nathan D. Burkett-Cadena
}

\begin{abstract}
Everglades virus (EVEV), subtype II within the Venezuelan equine encephalitis (VEE) virus complex, is a mosquitoborne zoonotic pathogen endemic to south Florida, USA. EVEV infection in humans is considered rare, probably because of the sylvatic nature of the vector, the Culex (Melanoconion) cedecei mosquito. The introduction of $C x$. panocossa, a tropical vector mosquito of VEE virus subtypes that inhabits urban areas, may increase human EVEV exposure. Field studies investigating spatial and temporal patterns of abundance, host use, and EVEV infection of $C x$. cedecei mosquitoes in Everglades National Park found that vector abundance was dynamic across season and region. Rodents, particularly Sigmodon hispidus rats, were primary vertebrate hosts, constituting $77 \%-100 \%$ of $C x$. cedecei blood meals. Humans were fed upon at several locations. We detected EVEV infection in Cx. cedecei mosquitoes in lower and upper regions of Everglades National Park only during the wet season, despite an abundance of $C x$. cedecei mosquitoes at other sampling times.
\end{abstract}

E verglades virus (EVEV) is a mosquitoborne alphavirus endemic to the state of Florida, USA, and is subtype II within the Venezuelan equine encephalitis (VEE) complex (1). The mosquito Culex (Melanoconion) cedecei is the sole enzootic vector of EVEV (2-4); rodents, particularly Peromyscus gossypinus (cotton mouse) and Sigmodon hispidus (hispid cotton rat), are the primary reservoir hosts (5-7). Clinical cases of EVEV infection in humans are considered rare; symptoms consist of nonspecific influenzalike febrile illness that can culminate in serious neurologic damage (1). The recent introduction and establishment of $C x$. panocossa mosquitoes into Florida (8) could increase human exposure to EVEV because this species is a vector of endemic VEEV strains in Central America $(9,10)$ and is abundant in manmade waterways supporting water lettuce

Author affiliation: University of Florida, Vero Beach, Florida, USA

DOI: https://doi.org/10.3201/eid2506.180338
$(8,11)$. Studies in Panama concluded that $C x$. panocossa (as $C x$. aikenii) mosquitoes were the most important VEE vector on the basis of high VEE experimental transmission rates (9), high experimental infection rates (9), high population density (9), and feeding upon VEE reservoir hosts $(10,11)$. The establishment of $C x$. panocossa mosquitoes in urban areas could link sylvatic transmission foci of EVEV with densely populated areas such as the greater Miami metropolitan area through vegetated canals (8).

Evidence of sporadic human infections with EVEV in south Florida in the 1960s $(12,13)$ spurred numerous field and laboratory studies to investigate the natural transmission cycle of the virus, focusing on determining the natural vectors and reservoirs of EVEV. These studies concluded that $C x$. cedecei mosquitoes transmit EVEV between the amplifying rodent hosts (cotton mouse and hispid cotton rat) (2-6) in hammocks of the Greater Everglades ecosystem. Although EVEV vector and reservoirs were firmly incriminated, researchers repeatedly encountered unexplained large heterogeneity in EVEV transmission, even at very small scales, in Florida. For example, Chamberlain et al. (2) found that EVEV infection rates in vectors ranged from $0.18 \%(\mathrm{n}=533)$ to $1.7 \%(\mathrm{n}=58)$ in Culex (Melanoconion) spp. mosquitoes at 3 of 4 Everglades research areas in 1963 and 1964, but the virus was not recovered from Pahay-okee Overlook, despite relatively high exposure rates $(20 \%)$ in rodents at that site (2). At Mahogany Hammock, 12 EVEV isolations were made from Culex (Melanoconion) females (average infection rate $0.53 \%$ ), even though exposure rates in rodents at Mahogany Hammock were lower than at Pa-hay-okee (2). In subsequent field studies north of Everglades National Park (ENP), Bigler et al. (14) demonstrated that EVEV appeared and circulated at different time periods during the year at 2 hammocks, despite their similarity and proximity $(<3 \mathrm{~km})$. Although the density of cotton mice varied between hammocks, the populations and seasonal fluctuations in age ratios and breeding 
activity were comparable (14). The moderate abundance and low levels of EVEV activity in vectors led the researchers to hypothesize that mechanisms other than host densities, populations, age structure, and mosquito infection all contributed to fluctuations of EVEV transmission between the 2 hammocks (14).

We conducted our study to quantify the spatial and seasonal patterns of abundance, host use, and EVEV infection of $C x$. cedecei mosquitoes in ENP to explore potential explanations for heterogeneity in EVEV prevalence observed in prior studies. We aspirated resting adult mosquitoes from 15 locations along $\approx 50 \mathrm{~km}$ of Main Park Road of ENP, where endemic EVEV transmission has been demonstrated in past studies. We used PCR assays to quantify host associations and EVEV infection in the mosquitoes and used logistic regression to investigate associations between EVEV infection, vector abundance, and host use.

\section{Methods}

We sampled mosquitoes in a variety of habitats along Main Park Road from the Everglades Visitor Center to Flamingo (permit EVER-2015-SCI-0054). The sampling locations were divided into 3 regions, upper, middle, and lower, representing natural physiographic regions of south Florida (Table 1; Figure 1). The upper region, from Royal Palm North $\left(25^{\circ} 24^{\prime} 08.3^{\prime \prime} \mathrm{N}, 80^{\circ} 36^{\prime} 56.7^{\prime \prime} \mathrm{W}\right)$ to Pa-hay-okee South $\left(25^{\circ} 25^{\prime} 56.0^{\prime \prime} \mathrm{N}, 80^{\circ} 46^{\prime} 38.9^{\prime \prime} \mathrm{W}\right)$, was dominated by large expanses of upland pine or hardwood forest. The middle region, from just south of Pa-hay-okee South extending to Nine Mile Pond $\left(25^{\circ} 15^{\prime} 14.1^{\prime \prime} \mathrm{N}, 80^{\circ} 47^{\prime} 53.5^{\prime \prime} \mathrm{W}\right)$, was dominated by wet sawgrass prairie (Everglades marsh) with smaller hardwood hammocks (tree islands). The lower region, from Snake Bight Trail to Bear Lake Trail $\left(25^{\circ} 8^{\prime} 55.82^{\prime \prime} \mathrm{N}, 80^{\circ} 55^{\prime} 23.69^{\prime \prime} \mathrm{W}\right)$, was dominated by extensive mangrove swamp.

We aspirated all mosquitoes from resting shelters (15), except at Mahogany Hammock, where we targeted natural resting sites, such as fallen logs and deep recesses, to abide by permit restrictions. We performed aspirations using a modified handheld battery-powered vacuum (DustBuster BDH1800S; Black and Decker Corporation, https://www. blackanddecker.com) fitted with a funnel and stainless-steel mesh-bottom collection cup (BioQuip model 2846D; BioQuip Products, Inc., https://www.bioquip.com), as described previously $(16,17)$. Resting shelters were equivalent in size

\begin{tabular}{|c|c|c|c|c|c|c|}
\hline Region & Site name and coordinates & Habitat & Mos. sampled & $\begin{array}{c}\text { No. resting } \\
\text { shelter days* }\end{array}$ & $\begin{array}{l}\text { Total no. } \\
\text { females }\end{array}$ & $\begin{array}{c}\text { No. females/ } \\
\text { shelter-day }\end{array}$ \\
\hline \multirow[t]{6}{*}{ Upper } & $\begin{array}{c}\text { Royal Palm North, } 25^{\circ} 24^{\prime} 7.43^{\prime \prime} \mathrm{N}, \\
80^{\circ} 36^{\prime} 56.40^{\prime \prime} \mathrm{W}\end{array}$ & $\begin{array}{c}\text { Extensive hardwood } \\
\text { hammock }\end{array}$ & $\begin{array}{l}\text { Feb, May, Jun, } \\
\text { Aug }\end{array}$ & 60 & 810 & 13.50 \\
\hline & $\begin{array}{c}\text { Long Pine Key North, } 25^{\circ} 25^{\prime} 3.00^{\prime \prime} \mathrm{N} \text {, } \\
80^{\circ} 38^{\prime} 20.00^{\prime \prime} \mathrm{W}\end{array}$ & $\begin{array}{l}\text { Small island } \\
\text { hammock }\end{array}$ & Jun, Aug & 8 & 147 & 18.38 \\
\hline & $\begin{array}{l}\text { Long Pine Key Campground, } \\
25^{\circ} 24^{\prime} 0.10^{\prime \prime} \mathrm{N}, 80^{\circ} 39^{\prime} 35.40^{\prime \prime} \mathrm{W}\end{array}$ & $\begin{array}{l}\text { Extensive pine } \\
\text { rockland }\end{array}$ & Feb & 4 & 5 & 1.25 \\
\hline & $\begin{array}{c}\text { Pinelands, } 25^{\circ} 25^{\prime} 24.80^{\prime \prime} \mathrm{N} \\
80^{\circ} 40^{\prime} 47.00^{\prime \prime} \mathrm{W}\end{array}$ & $\begin{array}{l}\text { Extensive pine } \\
\text { rockland }\end{array}$ & May, Jun, Aug & 44 & 107 & 2.43 \\
\hline & $\begin{array}{c}\text { Pa-hay-okee South, } 25^{\circ} 25^{\prime} 56.00^{\prime \prime} \mathrm{N} \text {, } \\
80^{\circ} 46^{\prime} 38.90^{\prime \prime} \mathrm{W}\end{array}$ & $\begin{array}{l}\text { Small island } \\
\text { hammock }\end{array}$ & Feb, May & 18 & 1 & 0.06 \\
\hline & $\begin{array}{c}\text { Pa-hay-okee Overlook, } \\
25^{\circ} 26^{\prime} 27.20^{\prime \prime} \mathrm{N}, 80^{\circ} 47^{\prime} 1.60^{\prime \prime} \mathrm{W}\end{array}$ & $\begin{array}{l}\text { Large island } \\
\text { hammock }\end{array}$ & Jun, Aug & 24 & 24 & 1.00 \\
\hline \multirow[t]{6}{*}{ Middle } & $\begin{array}{l}\text { Ficus Pond, } 25^{\circ} 21^{\prime} 24.00^{\prime \prime} \mathrm{N} \\
80^{\circ} 49^{\prime} 20.00^{\prime \prime} \mathrm{W}\end{array}$ & $\begin{array}{l}\text { Small island } \\
\text { hammock }\end{array}$ & Jun, Aug & 8 & 47 & 5.88 \\
\hline & $\begin{array}{l}\text { Mahogany Hammock East, } \\
25^{\circ} 20^{\prime} 20.00^{\prime \prime} \mathrm{N}, 80^{\circ} 49^{\prime} 4.80^{\prime \prime} \mathrm{W}\end{array}$ & $\begin{array}{l}\text { Small island } \\
\text { hammock }\end{array}$ & $\begin{array}{l}\text { Feb, May, Jun, } \\
\text { Aug }\end{array}$ & 50 & 287 & 5.74 \\
\hline & $\begin{array}{c}\text { Mahogany Hammock, } \dagger \\
25^{\circ} 19^{\prime} 22.50^{\prime \prime} \mathrm{N}, 80^{\circ} 49^{\prime} 59.40^{\prime \prime} \mathrm{W}\end{array}$ & $\begin{array}{l}\text { Large island } \\
\text { hammock }\end{array}$ & May, Jun & 4 & 2 & 0.50 \\
\hline & $\begin{array}{c}\text { Sweet Bay Pond, } 25^{\circ} 19^{\prime} 55.00^{\prime \prime} \mathrm{N} \text {, } \\
80^{\circ} 48^{\prime} 10.00^{\prime \prime} \mathrm{W}\end{array}$ & $\begin{array}{l}\text { Small island } \\
\text { hammock }\end{array}$ & Jun, Aug & 8 & 16 & 2.00 \\
\hline & $\begin{array}{c}\text { Paurotis Pond, } 25^{\circ} 18^{\prime} 7.00^{\prime \prime} \mathrm{N} \\
80^{\circ} 47^{\prime} 56.00^{\prime \prime} \mathrm{W}\end{array}$ & $\begin{array}{l}\text { Small island } \\
\text { hammock }\end{array}$ & Jun, Aug & 8 & 42 & 5.25 \\
\hline & $\begin{array}{c}\text { Nine Mile Pond, } 25^{\circ} 15^{\prime} 13.93^{\prime \prime} \mathrm{N} \\
80^{\circ} 47^{\prime} 53.64^{\prime \prime} \mathrm{W}\end{array}$ & $\begin{array}{l}\text { Ecotone of prairie } \\
\text { and mangrove }\end{array}$ & $\begin{array}{l}\text { Feb, May, Jun, } \\
\text { Aug }\end{array}$ & 53 & 942 & 17.77 \\
\hline \multirow[t]{3}{*}{ Lower } & $\begin{array}{c}\text { Snake Bight Trail, } 25^{\circ} 11^{\prime} 59.87^{\prime \prime} \mathrm{N} \\
80^{\circ} 52^{\prime} 27.08^{\prime \prime} \mathrm{W}\end{array}$ & Mangrove swamp & $\begin{array}{l}\text { Feb, May, Jun, } \\
\text { Aug }\end{array}$ & 53 & 702 & 13.25 \\
\hline & $\begin{array}{c}\text { Coot Bay Pond, } 25^{\circ} 10^{\prime} 56.90^{\prime \prime} \mathrm{N} \\
80^{\circ} 53^{\prime} 51.80^{\prime \prime} \mathrm{W}\end{array}$ & Mangrove swamp & Feb & 6 & 28 & 4.67 \\
\hline & $\begin{array}{c}\text { Bear Lake Trail, } 25^{\circ} 8^{\prime} 55.82^{\prime \prime} \mathrm{N} \\
80^{\circ} 5523.69^{\prime \prime} \mathrm{W}\end{array}$ & $\begin{array}{l}\text { Extensive } \\
\text { cottonwood } \\
\text { hammock }\end{array}$ & $\begin{array}{l}\text { Feb, May, Jun, } \\
\text { Aug }\end{array}$ & 58 & 253 & 4.36 \\
\hline Totals & & & & 406 & 3,413 & 6.40 \\
\hline
\end{tabular}

${ }^{*}$ Resting shelter days is no. of resting shelters deployed $\times$ total no. days sampled.

†Natural aspirations were performed to abide by permit restrictions. 


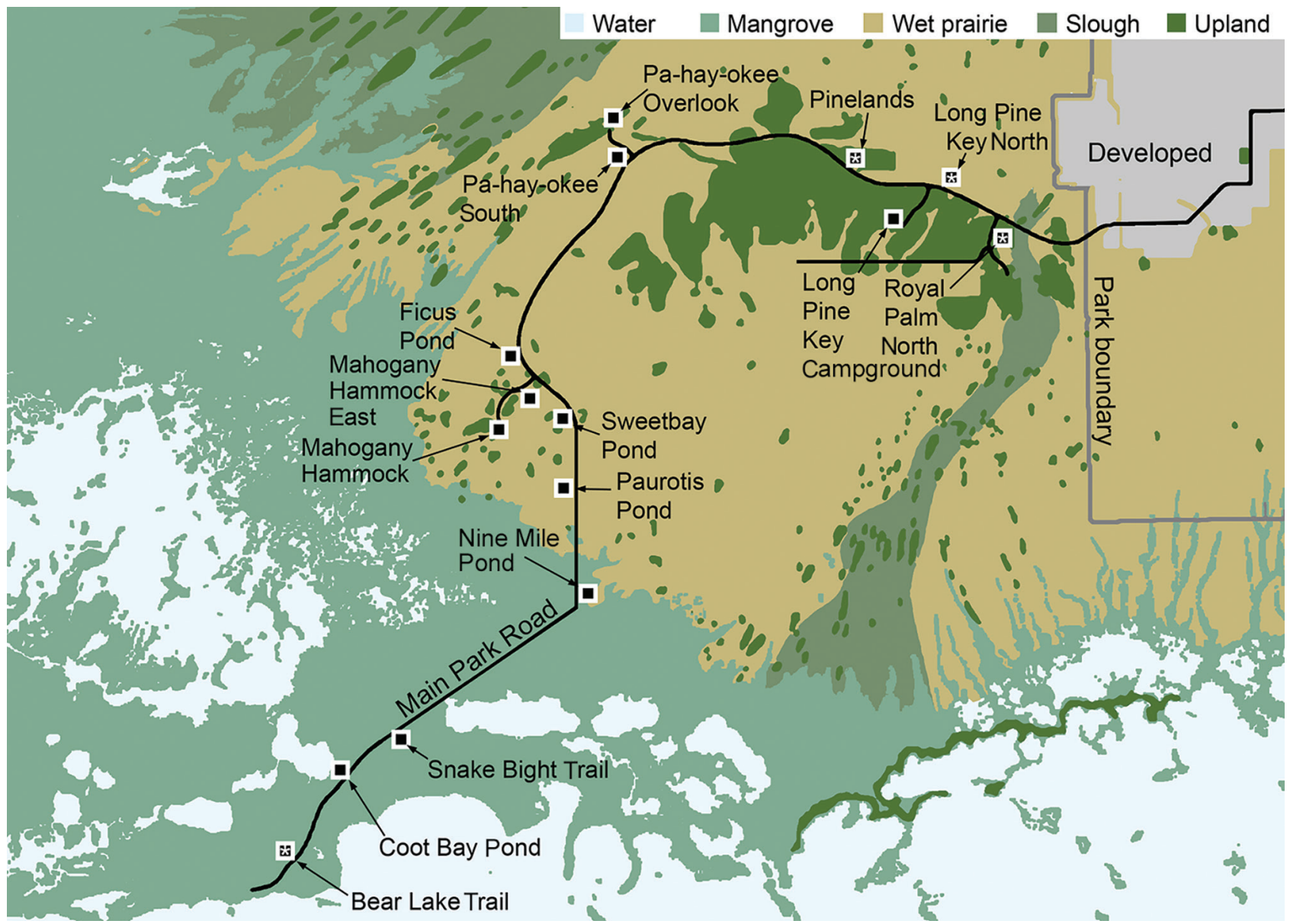

Figure 1. Everglades National Park, Florida, USA, showing dominant habitat types and sampling sites along Main Park Road. Black lines indicate paved roadways. Black squares indicate sampling sites; asterisks $\left(^{*}\right)$ within black squares denote detection of Everglades virus RNA in pooled Culex cedecei females by quantitative reverse transcription PCR.

and shape to previous models (15) but were constructed of PVC pipe and fittings so that they could be easily disassembled after each collecting trip, in accordance with permit requirements. We sampled a total of 406 resting shelter days in ENP, at a rate of 14-27 resting shelters per sampling period; we placed 1-5 shelters at each site and sampled them for 3-5 consecutive days between 7:00 AM and 1:00 PM. We placed resting shelters in areas with maximum shade within $90 \mathrm{~m}$ of Main Park Road or $45 \mathrm{~m}$ of trails. Sampling occurred within the Everglades dry season (in February and May) and wet season (in June and August) of 2016.

We identified mosquitoes to species using morphological features of the adult (16). Because of well-known difficulties of identifying Culex (Melanoconion) females $(17,18)$, we initially confirmed identifications by morphology of the cibarial armature (17) and molecular assays targeting the $18 \mathrm{~s}$ mitochondrial gene (18). Narrow decumbent scales of the vertex (19) served as a helpful diagnostic feature to separate $C x$. cedecei from other Culex (Melanoconion) spp. in Florida.
We performed blood meal analysis on individual blood-engorged $C x$. cedecei females using published PCR-based techniques (20). We amplified extracted DNA using PCR assays targeting cytochrome B and 16s rRNA genes of vertebrate hosts. We initially screened samples to identify blood meals from mammalian and amphibian hosts, using primers $\mathrm{L} 2513 / \mathrm{H} 2714$ (21) that target 16S rRNA of the host animal (20). We then screened samples that produced no amplicon using primer pairs $\mathrm{L} 0 / \mathrm{H} 1$ and/ or L0/H0, both targeting the cytochrome b gene of birds (22), and primer pair $16 \mathrm{~L} 1 / \mathrm{H} 3056$ used in phylogenetic studies of reptiles $(23,24)$. Primer sequences and cycling conditions are described in Blosser et al. (20). We sent PCR products to Eurofins Scientific (https://www. eurofins.com) for Sanger sequencing (forward direction only). We aligned sequences with published sequences in the National Center of Biotechnology Information sequence database using BLAST (https://blast.ncbi.nlm. nih.gov/Blast.cgi). We considered nucleotide similarity $\geq 95 \%$ a positive match. We maintained cold chain for 
all samples from the time of capture until DNA/RNA extraction. To minimize host DNA cross-contamination during sorting and processing, we handled specimens by their legs (to avoid puncturing the abdomen) using clean forceps and gloved hands. In general, blood-engorged females from resting shelters were fully intact, with no evidence of ruptured abdomens. We discarded any specimen with ruptured abdomen.

We screened RNA extracts (QIAamp viral RNA mini kit; QIAGEN, https://www.qiagen.com) from pooled $C x$. cedecei females for presence of EVEV RNA using quantitative reverse transcription PCR (qRTPCR) assay with $\left(5^{\prime} \rightarrow 3^{\prime}\right)$ primers (forward: CGAGGAGCTGTTTAAGGAGTATAA; reverse: CCTCTATGGCTATTGGGCTATG) and probe (6-FAM/ CGTTAGGTGTGCCGTTGGGAGTT/3BHQ1/) targeting EVEV nucleocapsid structural protein (primers/probes design by Integrated DNA Technologies, https://www. idtdna.com). Cycling conditions were $50^{\circ} \mathrm{C}(30 \mathrm{~min}), 95^{\circ} \mathrm{C}$ $(2 \mathrm{~min})$, then 40 cycles of $95^{\circ} \mathrm{C}(15 \mathrm{~s})$ and $61^{\circ} \mathrm{C}(1 \mathrm{~min})$. For assay validation we used EVEV strain FE3-7C, obtained from the Centers for Disease Control and Prevention, propagated on Vero cells using standard techniques $(25,26)$. Mosquito pools consisted of $\leq 32$ unfed and gravid $C x$. cedecei females aggregated by month and site. We determined samples with $\mathrm{C}_{\mathrm{t}}$ values $<33$ to be positive for EVEV RNA.

\section{Statistical Analysis}

We used Poisson regression modeling $(27,28)$ to test for statistically significant differences in mosquito abundance between wet and dry seasons for each of the most commonly collected mosquito species in each region, using Akaike information criterion (AIC) and the ratio of the Poisson regression coefficients to the SE (z) as test statistics. We calculated mosquito abundance as the number of females per shelter per sampling day. Only sites that were sampled during all sampling months were included in the analysis: Royal Palm North and Pinelands (upper), Mahogany Hammock East and Nine Mile Pond (middle), and Snake Bight Trail and Bear Lake Trail (lower). We performed $\chi^{2}$ test of independence to determine whether $C x$. cedecei blood meals were distributed differently among host species between season and region. Using multiple logistic regression, we determined whether vector abundance or reservoir host use better predicted detection of EVEV RNA from pooled mosquitoes. We quantified reservoir host use as the number of hispid cotton rat or cotton mouse blood meals per resting shelter per day. We performed statistical tests using R Studio version 3.4.3 (https://www.rstudio.com) and SAS version 9.4 (https://www.sas.com). For all statistical tests, $\alpha=0.05$.

\section{Results}

Cx. cedecei mosquito abundance varied across season and region (Figure 2, panel A). Females were significantly more abundant in the wet season in upper $(\mathrm{AIC}=228.22$, $\mathrm{z}=6.488 ; \mathrm{p}<0.001)$ and middle $(\mathrm{AIC}=295.24, \mathrm{z}=3.811$; $\mathrm{p}<0.001)$ regions of the Everglades but significantly
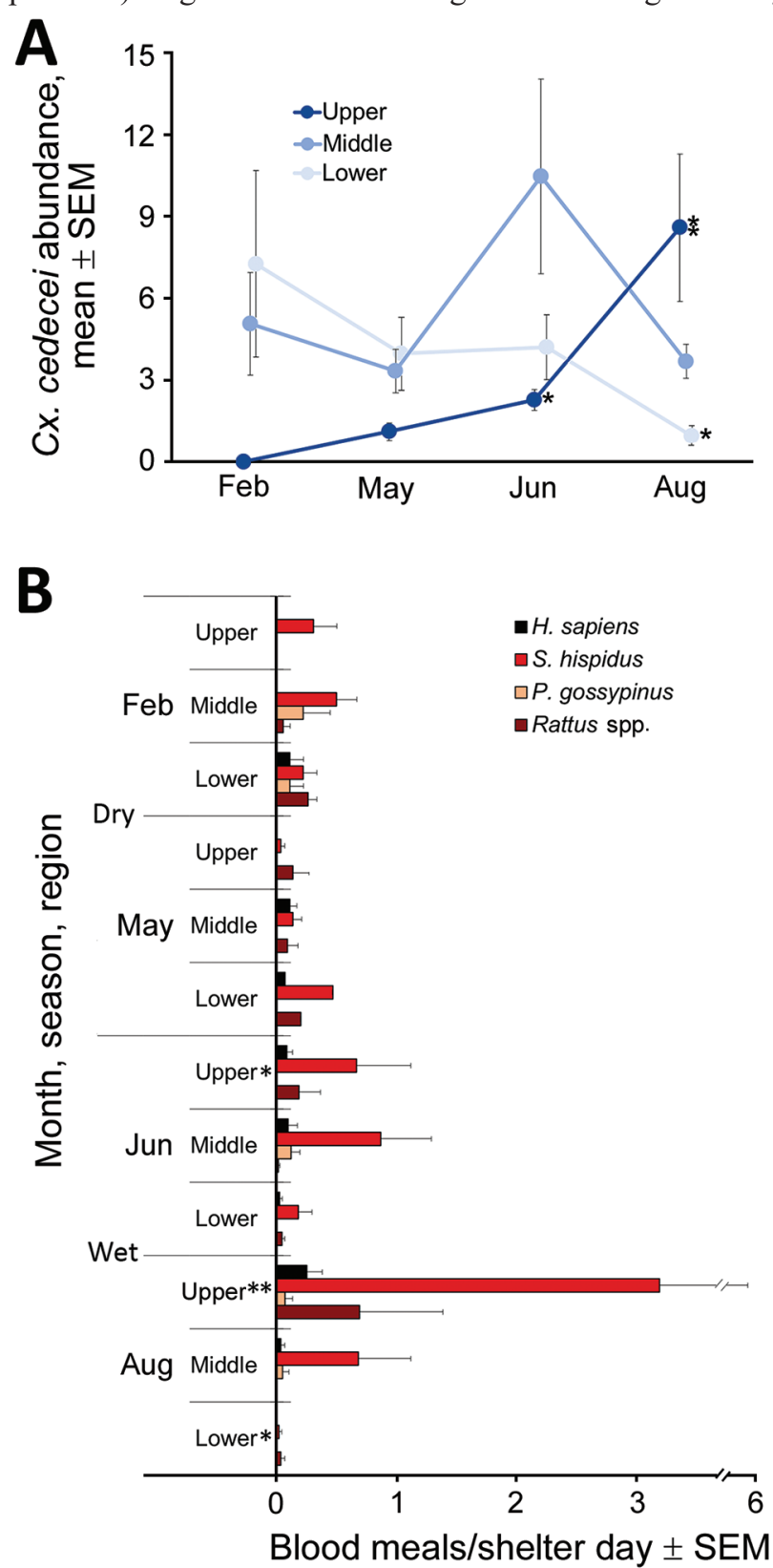

Figure 2. Regional and seasonal abundance and host use of Culex cedecei mosquitoes in Everglades National Park, Florida, USA. Wet season is April-October, and dry season is November-March. Each asterisk $\left(^{*}\right)$ denotes a pool of $C x$. cedecei females that tested positive for Everglades virus RNA by quantitative reverse transcription PCR. A) Average number of females aspirated from resting shelters by month. B) Host use by Cx. cedecei mosquitoes, represented as blood meals per resting shelter day by region and season. 
more abundant during the dry season in the lower region $(\mathrm{AIC}=251.2, \mathrm{z}=-3.897 ; \mathrm{p}<0.001)$. No other mosquito species exhibited a pattern of greater abundance during the dry season in any region (Appendix Table 1, https:// wwwnc.cdc.gov/EID/article/25/6/18-0338-App1.xlsx). For all other commonly collected mosquito species, abundance was greater during the wet season than dry season in all areas, although differences were not always significant (Appendix Table 1). Even within a single region and sampling period, $C x$. cedecei mosquito abundance varied considerably. For example, we collected 13.50 females per resting shelter at Royal Palm North (60 shelter days), whereas we collected 2.43 females per resting shelter at Pinelands (44 shelter days); the distance between the sites was only $\approx 6.7 \mathrm{~km}$.

The distribution of host species blood meals was significantly different spatially $\left(\chi^{2}=90.90, \mathrm{df}=20 ; \mathrm{p}<0.001\right)$ between the lower, middle, and upper regions of ENP (Figure 2, panel B) but not seasonally $\left(\chi^{2}=14.49, \mathrm{df}=10 ; \mathrm{p}\right.$ $=0.152$ ) (Figure 2, panel B). Rodents accounted for $77 \%$ $100 \%$ of the 347 total identifiable blood meals $(77.0 \%$ of 451 samples returning $\geq 95 \%$ match), depending on season and region (Table 2). Blood meals from EVEV reservoirs (hispid cotton rat and cotton mouse combined) were a large percentage of total blood meals from all regions, constituting $48 \%$ of total blood meals from the lower, $84 \%$ from the middle, and 50\% from the upper ENP region (Table 2). Reservoir host blood meals originated overwhelmingly from hispid cotton rat (Table 2; Figure 2, panel B), regardless of region or season. However, cotton mouse blood meals were relatively more common in the dry season in the lower and middle ENP (Figure 2, panel B). Blood meals from invasive Rattus spp. rodents contributed to the significant difference in distribution of host blood meals by region, such that much higher numbers of Rattus spp. blood meals were encountered in upper $(40 \%)$ and lower $(30 \%)$ than middle $(2 \%)$ regions of ENP (Figure 2, panel B). Blood meals obtained from humans constituted $7.53 \%$ of total blood meals and were detected in all 3 regions and seasons. All other hosts constituted $<1 \%$ of $C x$. cedecei host blood meals (Table 2; Appendix Table 2).

Although the distribution of blood meals from different host species did not vary substantially between seasons, the number of blood meals from reservoir hosts by season and region did (Figure 2, panel B). The number of hispid cotton rat-fed females per resting shelter day was greatest in the wet season in the upper region, peaking at 3.20 hispid cotton rat blood meals per shelter-day in August in the upper region. By contrast, we encountered 0.02 hispid cotton rat blood meals per shelter-day in lower ENP that same month (Figure 2, panel B).

In total, we screened 3,673 females $(1,326$ in dry season, and 2,347 in wet season) for EVEV RNA by RTPCR (average pool size \pm SD of $22 \pm 6$ females) (Table 1), including 3,413 females from resting shelters and 260 females aspirated from natural resting sites. We found 4 pools of $C x$. cedecei females, all of which were from the wet season (June or August), to be positive for EVEV by RT-PCR. These EVEV-positive pools included 1 pool of 25 females from Pinelands (upper region) in June $\left(C_{t}=21.3\right)$, 1 pool of 8 females from Bear Lake Trail (lower region) in August $\left(C_{t}=21.8\right), 1$ pool of 25 females from Royal Palm North (upper region) in August $\left(\mathrm{C}_{\mathrm{t}}=24.8\right)$, and 1 pool of 25 females from Long Pine Key North (upper region) in August $\left(\mathrm{C}_{\mathrm{t}}=24.5\right)$. Multiple logistic regression showed no association between EVEV RNA detected in pooled $C x$. cedecei and Cx. cedecei abundance, reservoir (hispid cotton rat plus cotton mouse) host use, or proportion of blood meals from reservoir hosts $\left(\chi^{2}=4.08, d f=3 ; p=0.252\right)$.

\section{Discussion}

The dynamic nature of $C x$. cedecei mosquito abundance is probably shaped by seasonal fluctuations in water levels through the seasonal filling and depletion of limestone solution holes (pits in karst that formed when sea level was lower than present levels), which constitute the primary habitat of $C x$. cedecei larvae (29). The contrasting patterns of $C x$. cedecei abundance in lower and upper regions of

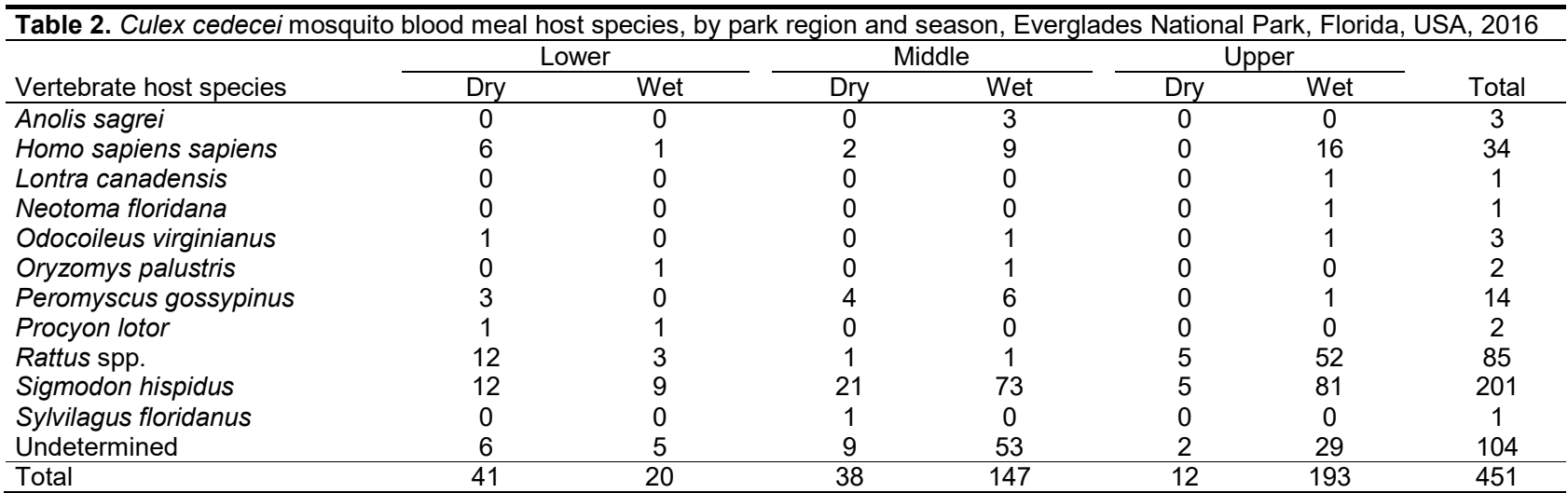


ENP suggest that Everglades hydrology has a strong influence on the seasonal reproductive biology of $C x$. cedecei mosquitoes, which may have consequences for EVEV transmission. In addition, the finding that $C x$. cedecei was the only mosquito species more abundant in dry season in the lower region of ENP suggests that the positive association between precipitation and abundance of other mosquito species may not apply consistently for this species. Our study did not quantify precipitation nor the availability of larval habitat, so explanations of the links between season, region, and $C x$. cedecei abundance are speculative. One possible explanation for the higher abundance of $C x$. cedecei mosquitoes during the dry season in the lower region is seasonal drying in the low-elevation lower Everglades: during times of higher water, aquatic predators, particularly fish, disperse rapidly throughout $\operatorname{ENP}(30,31)$, whereas isolated pockets of water without fish may be more abundant during the dry season. Detailed field and laboratory studies focusing on the ecology of immature stages are needed to understand the mechanisms driving these contrasting patterns of $C x$. cedecei abundance throughout the Everglades.

Variation in $C x$. cedecei host use between regions has important implications for understanding the transmission of EVEV in Florida. Our data demonstrate that Cx. cedecei mosquitoes feed heavily on mammals; rodents make up a substantial portion of hosts, regardless of season or region. The finding that hispid cotton rat and cotton mouse together constituted a large portion $(43.0 \%-86.2 \%)$ of $C x$. cedecei blood meals confirms a strong association between $C x$. cedecei mosquitoes and these EVEV reservoir host species $(3,14)$. Both hispid cotton rat and cotton mouse are common throughout Florida, so their role in EVEV transmission is probably limited by the distribution and abundance of $C x$. cedecei mosquitoes. However, the introduction and establishment of $C x$. panocossa mosquitoes in Florida may change this dynamic, resulting in more areas at risk for EVEV transmission (8).

The importance of Rattus spp. rodents as hosts of EVEV in lower and upper regions of ENP bears additional investigation, because these rats were relatively common hosts of $C x$. cedecei mosquitoes in these regions $(20.0 \%-$ $55.5 \%$ of total). We expect the lower and upper regions of the park, because of their proximity to park boundaries, campgrounds, parking lots, and human activity, to host larger populations of invasive rats than the middle region of ENP, which is comparatively undisturbed. Little information is available on the importance of Rattus spp. rodents as hosts of EVEV. Sanmartin et al. (32) made 4 isolations of VEEV from 41 Rattus spp. rodents sampled during an epizootic of VEEV in El Carmelo, Colombia, where subtypes IAB and IC circulate. In Florida, Bigler (33) detected EVEV antibodies in $12.5 \%(\mathrm{n}=40) R$. rattus rats sampled east of ENP. These findings suggest that these widespread, invasive rats might also support the transmission of EVEV in Florida, although laboratory host competence studies are needed to address this hypothesis.

The regions of the park in which human footprint is greatest also had the greatest relative numbers of human blood meals (11.48\% lower; $7.80 \%$ upper), compared with findings from the middle region (5.95\%). These relatively high levels of feeding suggest that $C x$. cedecei mosquitoes could serve not only as an enzootic and epizootic vector but also as a potential epidemic vector of EVEV where it comes into contact with humans.

The lack of a clear association between EVEV in pooled $C x$. cedecei females and vector abundance or metrics of host use is perplexing. Three of 4 EVEV-positive pools were from upper ENP during the wet season (1 in June, 2 in August), when $C x$. cedecei mosquitoes were more abundant (Figure 2, panel A) and obtained a large number of blood meals from cotton rats (Figure 2, panel B). Conversely, the EVEV-positive pool from lower ENP was also from the wet season (August), but $C x$. cedecei mosquito numbers were relatively low (Figure 2, panel A), and we observed very few blood meals from rodents (Figure 2, panel B). It is possible that wet-season transmission of EVEV is driven largely by the ecology and reproductive biology of cotton mouse and hispid cotton rat; however, a complex picture of rodent breeding and population dynamics emerges from past studies on this topic. Bigler et al. (14) concluded that the preponderance of EVEV amplification occurred between July and October, when dense populations of both cotton mice and cotton rats inhabited hammocks in the Pinecrest area on the ecotone between the Big Cypress Swamp and the Everglades ecosystem, $\approx 38 \mathrm{~km}$ northwest of the nearest sampling sites in our study. Lord et al. (34) screened mammals for EVEV antibodies in both Big Cypress Swamp and the Everglades, including the upper (Royal Palm Hammock) and middle (Mahogany Hammock) regions sampled in our study. Those results indicated that rodent breeding in these Everglades regions peaked in the dry season (January-February), a reversal of breeding patterns found farther north (14). Smith and Vrieze (35), working on hammocks of Taylor Slough (southeast Everglades), stated that all rodent reproduction occurred in the wet season. These contrasting results indicate that $S$. hispidus rats and $P$. gossypinus mice are likely to time their breeding to coincide with local conditions, which may be substantially different across locales. Our results are evidence of spatial variation in seasonality of EVEV transmission as observed in our work and that of others.

It was surprising that we did not detect EVEV in $C x$. cedecei mosquito samples from the middle region of ENP, despite relatively high $C x$. cedecei abundance (Figure 2, panel A), a relatively high biting rate on hispid cotton rats 
(Figure 2, panel B), and past evidence of EVEV circulation in mosquitoes in that region (2). Most $C x$. cedecei females sampled from the middle region $(70.5 \% ; 942 / 1,336$; Table 1) were captured at Nine Mile Pond on the ecotone between sawgrass marsh and mangrove swamps (Figure 1), a location for which historical data on EVEV prevalence is not available.

Although results of our work do not provide a complete understanding of EVEV transmission in ENP, they may help to clarify the perplexing heterogeneity observed in previous studies of EVEV in south Florida. The absence of EVEV in mosquitoes at Pa-hay-okee Overlook (2), for example, could be due to a near absence of $C x$. cedecei mosquitoes at that site (Table 1). Differences in EVEV transmission at 2 adjacent hammocks observed by Bigler et al. (14) could be a result of differences in vector abundance, contact rates, or both between vectors and reservoir versus nonreservoir hosts, as observed in our study. We did not quantify the actual abundance of reservoir hosts in the field, so it is possible that a given set of mosquitoes all could have fed on a small number (in low population settings) or a large number (greater populations) of rodents. Our measure of host usage could not account for those differences, nor could it account for how many of those rodents were actually susceptible hosts. The number of available susceptible reservoir hosts is an important factor in maintaining enzootic cycling of viruses. Our data do support conclusions of past studies that EVEV transmission occurs seasonally and is heterogeneous across ENP. Relative number of feedings on reservoir hosts differs across regions of the park, indicating the vector infection ratio may be higher in specific habitats where $C x$. cedecei mosquitoes have ample access to reservoir hosts, particularly young, virus-susceptible rodents.

Quantifying the spatial and temporal variation in abundance, host use, and virus infection of $C x$. cedecei mosquitoes is a step toward understanding the ecology of EVEV transmission in the United States. Findings that $C x$. cedecei mosquitoes feed on both reservoir hosts and humans in nature suggests that this insect could serve as both enzootic and epizootic vector. The establishment of the $C x$. panocossa mosquito in Florida, and its putative spread, may change the spatial risk for EVEV transmission, if found to be a competent vector. Future work should evaluate the host competence of Rattus spp. rodents for EVEV and other VEEV subtypes, evaluate vector competence of $C x$. panocossa mosquitoes for these viruses, and perform longitudinal studies of the focality of transmission in Florida.

\section{Acknowledgments}

We thank E. Blosser and L. Reeves for assistance in sampling and P. Walker for facilitating Everglades National Park permits. A. Carels Thompson performed molecular assays that contributed substantially to the results. We thank B. Russell for providing Everglades virus strain FE3-7C used to produce standard growth curves and validate RT-PCR assays. Two anonymous referees provided helpful comments to improve the manuscript.

This work was supported by IFAS Early Career Scientist Seed Grant and NIFA FLA-VME-005446.

\section{About the Author}

Mr. Hoyer is an entomologist for Project Premonition, a Microsoft Research endeavor to detect and track emerging infectious disease. His research interests include the ecology of vectorborne disease and its applications in public health for prevention of disease.

\section{References}

1. Weaver SC, Ferro C, Barrera R, Boshell J, Navarro JC. Venezuelan equine encephalitis. Annu Rev Entomol. 2004;49:14174. http://dx.doi.org/10.1146/annurev.ento.49.061802.123422

2. Chamberlain RW, Sudia WD, Work TH, Coleman PH, Newhouse VF, Johnston JG Jr. Arbovirus studies in south Florida, with emphasis on Venezuelan equine encephalomyelitis virus. Am J Epidemiol. 1969;89:197-210. http://dx.doi.org/10.1093/ oxfordjournals.aje.a120929

3. Edman JD. Host-feeding patterns of Florida mosquitoes (Diptera: Culicidae) VI. Culex (Melanoconion). J Med Entomol. 1979;15:521-5. http://dx.doi.org/10.1093/jmedent/15.5-6.521

4. Weaver SC, Scherer WF, Taylor CA, Castello DA, Cupp EW. Laboratory vector competence of Culex (Melanoconion) cedecei for sympatric and allopatric Venezuelan equine encephalomyelitis viruses. Am J Trop Med Hyg. 1986;35:619-23. http://dx.doi.org/10.4269/ajtmh.1986.35.619

5. Bigler WJ, Lewis AL, Wellings FM. Experimental infection of the cotton mouse (Peromyscus gossypinus) with Venezuelan equine encephalomyelitis virus. Am J Trop Med Hyg. 1974a;23:1185-8. http://dx.doi.org/10.4269/ajtmh.1974.23.1185

6. Coffey LL, Carrara AS, Paessler S, Haynie ML, Bradley RD, Tesh RB, et al. Experimental Everglades virus infection of cotton rats (Sigmodon hispidus). Emerg Infect Dis. 2004;10:2182-8. http://dx.doi.org/10.3201/eid1012.040442

7. Carrara AS, Coffey LL, Aguilar PV, Moncayo AC, Da Rosa AP, Nunes MR, et al. Venezuelan equine encephalitis virus infection of cotton rats. Emerg Infect Dis. 2007;13:1158-65. http://dx.doi.org/10.3201/eid1308.061157

8. Blosser EM, Burkett-Cadena ND. Culex (Melanoconion) panocossa from peninsular Florida, USA. Acta Trop. 2017;167:5963. http://dx.doi.org/10.1016/j.actatropica.2016.12.024

9. Galindo P, Grayson MA. Culex (Melanoconion) aikenii: natural vector in Panama of endemic Venezuelan encephalitis. Science. 1971;172:594-5. http://dx.doi.org/10.1126/science.172.3983.594

10. Tempelis $\mathrm{CH}$, Galindo P. Host-feeding patterns of Culex (Melanoconion) and Culex (Aedinus) mosquitoes collected in Panama. J Med Entomol. 1975;12:205-9. http://dx.doi.org/10.1093/ jmedent/12.2.205

11. Galindo P, Adames AJ. Ecological profile of Culex (Melanoconion) aikenii (Diptera: Culicidae), vector of endemic Venezuelan encephalitis in Panama. Environ Entomol. 1973;2:81-6. http://dx.doi.org/10.1093/ee/2.1.81

12. Work TH. Serological evidence of arbovirus infection in the Seminole Indians of southern Florida. Science. 1964;145:270-2. http://dx.doi.org/10.1126/science.145.3629.270 
13. Ehrenkranz NJ, Sinclair MC, Buff E, Lyman DO. The natural occurrence of Venezuelan equine encephalitis in the United States. N Engl J Med. 1970;282:298-302. http://dx.doi.org/10.1056/ NEJM197002052820603

14. Bigler WJ, Ventura AK, Lewis AL, Wellings FM, Ehrenkranz NJ. Venezuelan equine encephalomyelitis in Florida: endemic virus circulation in native rodent populations of Everglades hammocks. Am J Trop Med Hyg. 1974b;23:513-21. http://dx.doi.org/10.4269/ ajtmh.1974.23.513

15. Burkett-Cadena ND. A wire-frame shelter for collecting resting mosquitoes. J Am Mosq Control Assoc. 2011;27:153-5. http://dx.doi.org/10.2987/10-6076.1

16. Darsie RF Jr, Morris CD. Keys to the adult females and fourth instar larvae of the mosquitoes of Florida (Diptera, Culicidae). Technical Bulletin of the Florida Mosquito Control Association. Vero Beach (FL): Florida Mosquito Control Association; 2003.

17. Williams MR, Savage HM. Identification of Culex (Melanoconion) species of the United States using female cibarial armature (Diptera: Culicidae). J Med Entomol. 2009;46:745-52. http://dx.doi.org/10.1603/033.046.0404

18. Williams MR, Savage HM. Development of multiplexed species specific polymerase chain reaction assays for identification of the Culex (Melanoconion) species (Diptera: Culicidae) of the southeastern United States based on rDNA. J Med Entomol. 2011;48:961-6. http://dx.doi.org/10.1603/ME11081

19. Sallum MA, Forattini OP. Revision of the Spissipes section of Culex (Melanoconion) (Diptera:Culicidae). J Am Mosq Control Assoc. 1996;12:517-600.

20. Blosser EM, Stenn T, Acevedo C, Burkett-Cadena ND. Host use and seasonality of Culex (Melanoconion) iolambdis (Diptera: Culicidae) from eastern Florida, USA. Acta Trop. 2016;164:352-9. http://dx.doi.org/10.1016/j.actatropica.2016.10.001

21. Kitano T, Umetsu K, Tian W, Osawa M. Two universal primer sets for species identification among vertebrates. Int J Legal Med. 2007;121:423-7. http://dx.doi.org/10.1007/s00414-006-0113-y

22. Lee JC, Tsai LC, Huang MT, Jhuang JA, Yao CT, Chin SC, et al. A novel strategy for avian species identification by cytochrome $b$ gene. Electrophoresis. 2008;29:2413-8. http://dx.doi.org/10.1002/ elps.200700711

23. Hass CA, Hedges SB, Maxson LR. Molecular insights into the relationships and biogeography of West Indian anoline lizards. Biochem Syst Ecol. 1993;21:97-114. http://dx.doi. org/10.1016/0305-1978(93)90015-J

24. Vidal N, Kindl SG, Wong A, Hedges SB. Phylogenetic relationships of xenodontine snakes inferred from $12 \mathrm{~S}$ and $16 \mathrm{~S}$ ribosomal
RNA sequences. Mol Phylogenet Evol. 2000;14:389-402. http://dx.doi.org/10.1006/mpev.1999.0717

25. Alto BW, Lord CC. Transstadial effects of Bti on traits of Aedes aegypti and infection with dengue virus. PLoS Negl Trop Dis. 2016;10:e004370. http://dx.doi.org/10.1371/ journal.pntd.0004370

26. Alto BW, Wiggins K, Eastmond B, Velez D, Lounibos LP, Lord CC. Transmission risk of two chikungunya lineages by invasive mosquito vectors from Florida and the Dominican Republic. PLoS Negl Trop Dis. 2017;11:e0005724. http://dx.doi.org/10.1371/journal.pntd.0005724

27. Coxe S, West SG, Aiken LS. The analysis of count data: a gentle introduction to Poisson regression and its alternatives. J Pers Assess. 2009; 91:121-36. http://dx.doi.org/10.1080/00223890802634175

28. McElduff F, Cortina-Borja M, Chan SK, Wade A. When t-tests or Wilcoxon-Mann-Whitney tests won't do. Adv Physiol Ed. 2010:34:128-33. https://doi.org/10.1152/advan.00017.2010

29. Hair JA. Observations on two species of Culex of the subgenus Melanoconion. Mosq News. 1968;28:425-29.

30. DeAngelis DL, Trexler JC, Loftus WF. Life history trade-offs and community dynamics of small fishes in a seasonally pulsed wetland. Can J Fish Aquat Sci. 2005;62:781-90. http://dx.doi.org/ 10.1139/f05-050

31. DeAngelis DL, Trexler JC, Cosner C, Obaza A, Jopp F. Fish population dynamics in a seasonally varying wetland. Ecol Modell. 2010;221:1131-7. http://dx.doi.org/10.1016/ j.ecolmodel.2009.12.021

32. Sanmartín C, Mackenzie RB, Trapido H, Barreto P, Mullenax CH, Gutiérrez E, et al. Venezuelan equine encephalitis in Colombia, 1967 [in Spanish]. Bol Oficina Sanit Panam. 1973;74:108-37.

33. Bigler WJ. Venezuelan encephalitis antibody studies in certain Florida wildlife. Wildl Dis. 1969;5:267-70.

34. Lord RD, Calisher CH, Sudia WD, Work TH. Ecological investigation of vertebrate hosts of Venezuelan equine encephalomyelitis virus in south Florida. Am J Trop Med Hyg. 1973;22:116-23. http://dx.doi.org/10.4269/ajtmh.1973.22.116

35. Smith AT, Vrieze JM. Population structure of Everglades rodents: responses to a patchy environment. Journal of Mammalogy. 1979;60:778-94.

Address for correspondence: Nathan D. Burkett-Cadena, University of Florida-Florida Medical Entomology Laboratory, Institute of Food and Agricultural Science, Vero Beach, FL 32962, USA; email: nburkettcadena@ufl.edu 